\title{
KESENJANGAN AKSESIBILITAS UTARA DAN SELATAN KOTA SURAKARTA
}

\author{
Syarifa Khoirunnisa Suryana', Paramita Rahayu'1, Erma Fitria Rini ${ }^{1}$ \\ ${ }^{1}$ Program Studi Perencanaan Wilayah dan Kota, Fakultas Teknik, Universitas Sebelas Maret
}

\begin{abstract}
Abstrak
Penelitian ini ditujukan untuk mengetahui perbandingan aksesibilitas di wilayah utara dan selatan Kota Surakarta. Terjadinya kesenjangan perkembangan wilayah utara dengan wilayah selatan Kota Surakarta diduga karena adanya perbedaan aksesibilitas. Wilayah selatan lebih mengalami perkembangan akibat aksesibilitasnya dianggap lebih baik dibandingkan aksesibilitas di wilayah utara. Penelitian ini menggunakan pendekatan studi kasus dan pengumpulan data dilakukan melalui observasi, studi literatur, dan kuesioner dengan metode accidental sampling. Penelitian ini menerapkan teknik analisis statistika deskriptif dan komparasi rata-rata melalui uji z. Hasil penelitian menunjukkan wilayah selatan memiliki aksesibilitas tempat yang lebih baik dibandingkan wilayah utara. Aksesibilitas tempat di wilayah selatan didukung pola guna lahan yang mengelompok dan keberadaan transportasi publik yang melayani seluruh kawasan.
\end{abstract}

Kata kunci: aksesibilitas; guna lahan; perkembangan wilayah; transportasi publik

\begin{abstract}
This study aims atcomparing the accessibility in the northern and southern part of Surakarta City. The development gap between the northern and southern part of the City is presumed due to differences in accessibility. The southern prt of the city is more developed because of accessibility. The accessibility of that area is considered more developed than that in the northern part of the city. This study implements case study approach. Data is collected through observation, study literature and questionnaire based on accidental sampling method. This study applies descriptive statistical analysis techniques and comparison of the mean techniques through z test. The results showed that the southern part of Surakarta has better accessibility of locationthan the northern area. The accessibility of different location in the southern part of Surakarta is offered by a clustered land use pattern and the provision of public transportation servicing the entire southern area.
\end{abstract}

Keywords: accessibility; land use; public transportation; region development

\section{PENDAHULUAN}

Rencana Tata Ruang Kabupaten/Kota merupakan penyusunan dan penetapan struktur dan pola ruang kota ke dalam kebijakan dan strategi pengembangan kota yang mengacu kepada fungsi dan peran kota di dalam rencana pengembangan provinsi dan nasional. Kota Surakarta memiliki peran sebagai Pusat Kegiatan Nasional (PKN) dalam RTRW Nasional (Pemerintah Kota Surakarta, 2012). Hal tersebut tentu berdampak pada aktivitas perkotaan di Kota Surakarta. Kota dengan luas $46 \mathrm{~km}^{2}$ memiliki penduduk sebanyak 516.102 jiwa di tahun 2017 serta kepadatan penduduk mencapai 11.718,78 jiwa/km² (Badan Pusat Statistik, 2018).

Dalam RPJMD Kota Surakarta Tahun 2016-2021, dijabarkan bahwa Kota Surakarta memiliki enam Sub Pusat Pelayanan Kota (SPK) yang disesuaikan dengan potensi masing-masing kawasan (Pemerintah Kota Surakarta, 2016). Pembagian SPK kawasan ditujukan untuk mengoptimalkan peran Kota Surakarta sebagai PKN dan Kawasan Strategis Perkotaan dan kemudahan pengaturan ruang serta pelayanan. Berdasarkan RPJMD Kota Surakarta Tahun 2016-2021, SPK Kawasan III (utara) yang meliputi, Kelurahan Banyuanyar, Kadipiro, Nusukan, dan Sumber menjadi kawasan prioritas 1 dalam hal penanganan. Hal tersebut karena infrastruktur permukiman dan perhubungan di kawasan belum dikembangkan secara optimal 
sehingga perkembangan di kawasan atau wilayah utara lebih lambat dibandingkan dengan perkembangan wilayah selatan Kota Surakarta (Pemerintah Kota Surakarta, 2016).

Sedangkan, kawasan dengan prioritas terakhir adalah SPK Kawasan I (selatan). SPK Kawasan I (selatan) terdiri dari Kelurahan Penumping, Panularan, Sriwedari, Kemlayan, Jayengan, Kratonan, Tipes, Kauman, Baluwarti, Gajahan, Serengan, Danukusuman, Joyotakan, Joyosuran, Pasar Kliwon, Kedunglumbu, Gandekan, Sewu, Sangkrah, dan Semanggi. SPK Kawasan I merupakan area permukiman padat perkotaan, lokasi pariwisata keraton, industri kreatif, serta pusat perdagangan berskala regional. Banyaknya aktivitas di SPK Kawasan I tidak terlepas dari kemudahan masyarakat dalam mencapai guna lahan berbeda sehingga aksesibilitas di kawasan terbilang baik dan mendukung potensi kawasan. Menurut RTRW Kota Surakarta Tahun 2011-2031, wilayah selatan dikatakan berkembang lebih pesat dibandingkan wilayah utara Kota Surakarta karena aksesibilitasnya yang lebih baik dan lebih mendukung wilayah untuk berkembang (Pemerintah Kota Surakarta, 2012).

Perbedaan aksesibilitas antara wilayah utara dengan wilayah selatan Kota Surakarta dianggap berpengaruh terhadap perkembangan wilayah, di mana wilayah selatan Kota Surakarta lebih berkembang karena aksesibilitasnya yang lebih baik dari wilayah utara. Berdasarkan Rencana Tata Ruang Kota Surakarta, pengembangan pola ruang di wilayah utara diarahkan kepada pengembangan kawasan terbangun kota dan wilayah selatan diarahkan kepada peningkatan kualitas lingkungan hidup. Pengembangan kawasan terbangun kota ke arah utara menunjukkan bahwa wilayah utara Kota Surakarta merupakan kawasan yang masih belum terbangun dan berkembang. Di samping itu, kebijakan tersebut menunjukkan adanya dukungan agar perkembangan wilayah utara lebih optimal. Hal ini membuat pemerintah kota merencanakan pengembangan kawasan terbangun di wilayah utara. Berbeda dengan wilayah selatan yang diarahkan kepada peningkatan kualitas hidup. Hal ini berarti bahwa pembangunan di wilayah selatan sudah pada batas maksimal sehingga terjadi penurunan kualitas lingkungan hidup.

Perbedaan perkembangan wilayah antara SPK III (utara) dengan SPK I (selatan) menjadi gambaran kesenjangan wilayah yang terjadi di Kota Surakarta. Dalam RTRW Kota Surakarta Tahun 2011-2031, disebutkan bahwa kesenjangan wilayah terjadi karena terdapat perbedaan aksesibilitas antar kedua wilayah. Menurut Sumadi, Papia, \& Makainas (2017), aksesibilitas wilayah berhubungan erat dengan perkembangan wilayah. Faktor penentu yang menjadi acuan berkembanganya suatu wilayah, yaitu pola guna lahan (Samli, 2012). Hal yang mempengaruhi pola guna lahan, antara lain pola aksesibilitas dan pola jaringan jalan (Samli, 2012). Bila dilihat dari teori Black (1981) dalam Tamim (2000), aksesibilitas merupakan suatu ukuran kemudahan interaksi antar dua guna lahan atau lebih melalui sistem jaringan transportasi yang ada. Tinggi rendahnya aksesibilitas bergantung pada waktu tempuh, biaya/ongkos, intensitas (kepadatan) guna lahan, dan pendapatan orang yang melakukan perjalanan (Miro \& Hardani, 2005). Perbedaan aksesibilitas wilayah utara dan wilayah selatan diduga berpengaruh terhadap perkembangan wilayah di Kota Surakarta. Aksesibilitas wilayah utara Kota Surakarta yang belum optimal menyebabkan perkembangan wilayah utara tertinggal dari wilayah selatan sehingga muncul kesenjangan wilayah. Oleh karena itu, penelitian ini bertujuan untuk mengkaji perbedaan aksesibilitas wilayah utara dan selatan Kota Surakarta melalui gambaran aksesibilitas secara umum, komparasi rata-rata aksesibilitas, dan daya tarik kawasan di masing-masing wilayah.

\section{KAJIAN PUSTAKA}

\subsection{AKSESIBILITAS DALAM PERKEMBANGAN WILAYAH}

Dalam RTRW Kota Surakarta Tahun 2011 - 2031 disebutkan bahwa kesenjangan antara wilayah utara dengan selatan Kota Surakarta disebabkan oleh aksesibilitas di wilayah utara yang belum optimal (Pemerintah Kota Surakarta, 2012). Pemerintah Kota memprioritaskan pengembangan wilayah utara ke arah kawasan terbangun, sedangkan prioritas pengembangan wilayah selatan diarahkan kepada peningkatan kualitas hidup. Riyadi dan Bratakusumah (2005) dalam Sumadi et al. (2017) berpendapat bahwa salah satu upaya untuk mengurangi kesenjangan antar wilayah adalah melalui pembangunan wilayah. Hal ini sesuai dengan kondisi wilayah utara dengan selatan Kota Surakarta dan prioritas pengembangan wilayah. Sedangkan menurut Adisasmita dalam Sumadi et al. (2017), kemudahan masyarakat dalam memperoleh kebutuhan sehari-hari menjadi salah satu indikator perkembangan wilayah. Kemudahan dalam memperoleh kebutuhan sehari-hari merupakan konsep aksesibilitas menurut Black (1981) dalam Tamim (2000).

Berdasarkan Sumadi, Papia, \& Makainas (2017), terdapat hubungan yang erat antara aksesibilitas wilayah dengan perkembangan wilayah. Wilayah yang berkembang memiliki aksesibilitas wilayah lebih baik dibandingkan wilayah sekitarnya. 
Menurut Samli (2012), pola aksesibilitas dan pola jaringan jalan mempengaruhi pola penggunaan lahan. Pola aksesibilitas yang dimaksud merupakan pola persebaran fasilitas yang didukung trayek angkutan kota.

Samli (2012) berpendapat bahwa pola guna lahan merupakan faktor penentu dan acuan tumbuh kembang suatu wilayah. Di wilayah yang lebih berkembang didominasi oleh lahan terbangun. Wilayah dengan hirarki lebih tinggi memiliki tingkat perkembangan yang tinggi juga, yang mana pemanfaatan lahan di wilayah tersebut didominasi oleh lahan terbangun (Sitorus, Leonataris, \& Panuju, 2012).

\subsection{AKSESIBILITAS}

Aksesibilitas merupakan sebuah tahapan pertama dari hubungan antara sistem kegiatan, sistem jaringan, dan sistem pergerakan (Tamim, 2000). Menurut Tamin (2000), tahapan aksesibilitas dan mobilitas bersifat abstrak dibandingkan keempat tahapan berikutnya, yaitu pembangkit lalu lintas, sebaran penduduk, pemilihan moda transportasi, dan pemilihan rute. Hal ini dikarenakan aksesibilitas merupakan sebuah konsep mengenai kemudahan perjalanan. Semakin mudah aksesibilitas di suatu wilayah maka semakin berpeluang wilayah tersebut berkembang dan terbangun.

Black (1981) dalam Tamim (2000) berpendapat bahwa aksesibilitas merupakan suatu ukuran kemudahan interaksi antar dua guna lahan atau lebih yang dapat dicapai melalui sistem jaringan transportasi yang ada. Aksesibilitas adalah konsep yang menggabungkan sistem guna lahan dengan sistem jaringan transportasi sebagai penghubung. Aksesibilitas dapat diukur melalui jarak, waktu tempuh, dan frekuensi serta pelayanan transportasi yang ada. Untuk lebih memahami bagaimana pengukuran aksesibilitas dapat dilakukan, berikut merupakan skema sederhana dari Black (1981) dalam Tamim (2000) untuk mengklasifikasikan aksesibilitas secara kualitatif yang dapat dilihat pada Tabel 1.

Tabel 1. Klasifikasi Aksesibilitas secara Kualitatif

\begin{tabular}{ccc}
\hline Jarak/kondisi prasarana & Sangat jelek & Sangat baik \\
\hline Jauh & Aksesibilitas rendah & Aksesibilitas menengah \\
Dekat & Aksesibilitas menengah & Aksesibilitas tinggi \\
\hline Sumber: Tamim (2000) & &
\end{tabular}

Hal di atas menunjukkan bahwa tata guna lahan yang saling berdekatan dan kondisi hubungan transportasi baik maka aksesibilitas antar kedua guna lahan tinggi, sebaliknya jika aktivitas guna lahan berjauhan dan kondisi hubungan transportasi tidak memadai maka aksesibilitas antar kawasan rendah (Tamim, 2000). Tamim (2000) berpendapat bahwa konsep aksesibilitas berkaitan erat dengan kemampuan tarikan pergerakan. Kawasan dengan guna lahan yang intensif akan menarik pergerakan (Tamim, 2000)

Menurut Miro \& Hardani (2005), aksesibilitas atau tingkat kemudahan berbagai zona berhubungan dipengaruhi oleh sistem transportasi yang pola dan pelayanannya dibentuk dari kebijakan pemerintah suatu wilayah. Bila dua zona mudah dihubungkan, maka mobilitas yang ada di antara zona tersebut akan meningkat sehingga muncul kesimpulan bahwa aksesibilitas dapat mempengaruhi mobilitas di kawasan. Faktor-faktor yang dapat menentukan tinggi rendahnya akses adalah faktor waktu tempuh, faktor biaya/ongkos, faktor intensitas (kepadatan) guna lahan, faktor pendapatan orang yang melakukan perjalanan (Miro \& Hardani, 2005). Tingkat aksesibilitas wilayah juga dapat ditentukan dari kondisi tingkat kerusakan jalan terhadap luas wilayah di masing-masing kecamatan serta ketersediaan, frekuensi, tarif, dan jarak pelayanan angkutan umum (Kartikasari, Sitorus, \& Soma, 2017).

Menurut Fotini (2017), aksesibilitas dapat diukur melalui tiga persamaan baru, yaitu elemen spasial, temporal, travel. Elemen spasial berfungsi dalam menggambarkan kepentingan setiap aktivitas, sedangkan untuk elemen travel berkaitan dengan biaya perjalanan per hari, dan untuk elemen temporal diukur sebagai kehadiran individu dalam setiap kegiatan dalam sehari atau didefinisikan sebagai total jam harian. Persamaan baru tersebut menghasilkan jadwal aktivitas individu harian atau penjumlahan berbagai kegiatan sehari-hari (tetap dan fleksibel). Dalvi dan Martin (1976) dalam Kaza (2015) berpendapat bahwa perbedaan aksesibilitas suatu lokasi berasal dari perubahan atribut lokasi dan penarik (misalnya pekerjaan, jenis tujuan, jenis rumah tangga, dll.) dan ketertarikan terhadap aksesibilitas relatif dari satu lokasi terhadap yang lain. Adanya aksesibilitas yang tinggi dan semakin meluas, maka interaksi antar wilayah semakin intensif. Interaksi antar wilayah yang semakin intensif membuat wilayah semakin berkembang sehingga mendukung peningkatan kesejahteraan masyarakat dan mewujudkan 
masyarakat yang adil serta makmur (Adisasmita, 2015). Selain aksesibilitas tempat, aksesibilitas memiliki bentuk lain berupa aksesibilitas individu. Aksesibilitas individu menurut Martens (2012) adalah kemampuan individu dalam mengakses beberapa lokasi. Menurut Kwan dalam Martens (2012), aksesibilitas individu terbentuk dari ketersediaan moda, ketersediaan uang dan waktu, atau organisasi masyarakat.

\section{METODE PENELITIAN}

Penelitian ini bertujuan untuk melihat perbedaan aksesibilitas wilayah utara dan selatan Kota Surakarta yang diduga berpengaruh terhadap perkembangan kedua wilayah. Studi ini merupakan penelitian deduktif dengan menggunakan studi kasus. Penelitian ini menggunakan unit analisis Sub Pusat Pelayanan Kota (SPK) Surakarta yang terdiri dari 4 kelurahan untuk SPK III (utara) dan 20 kelurahan untuk SPK I (selatan). Variabel yang digunakan dalam penelitian seperti yang tertera pada Tabel 2, meliputi pola guna lahan, jaringan jalan, waktu tempuh, jarak tempuh, dan biaya transportasi.

Teknik pengumpulan data primer dalam penelitian ini dilakukan melalui observasi dan kuesioner. Pengumpulan data melalui observasi dilakukan untuk mengetahui perbandingan kondisi jaringan jalan. Di samping itu, pengumpulan data melalui kuesioner dilakukan untuk mengetahui rata-rata dari jarak tempuh, waktu tempuh, dan biaya transportasi di SPK III (utara) dan SPK I (selatan) Kota Surakarta. Pengumpulan data melalui kuesioner menggunakan metode accidental sampling untuk mengetahui pengalaman masyarakat dalam mengakses wilayah penelitian. Untuk pengumpulan data sekunder, penelitian ini menggunakan teknik studi literatur. Studi literatur dilakukan untuk melihat perbedaan luas proporsi lahan terbangun dan non terbangun serta pola sebaran guna lahan dari Badan Perencanaan Penelitian dan Pengembangan Daerah (BAPPPEDA) Kota Surakarta. Rentang waktu pengumpulan data adalah tujuh bulan, dimulai pada akhir bulan Maret hingga awal Oktober.

Tabel 2. Variabel Penelitian

\begin{tabular}{|c|c|c|c|c|}
\hline Variabel & Sub Variabel & Indikator & Parameter & Definisi Operasional Variabel \\
\hline $\begin{array}{l}\text { Kondisi guna lahan } \\
\text { wilayah }\end{array}$ & $\begin{array}{l}\text { Proposi luas lahan } \\
\text { terbangun dan non } \\
\text { terbangun } \\
\text { Jenis penggunaan } \\
\text { lahan }\end{array}$ & Pola sebaran & $\begin{array}{c}\text { - } \\
\text { Mengelompok, } \\
\text { acak, seragam }\end{array}$ & Perbandingan perkembangan wilayah \\
\hline $\begin{array}{l}\text { Kondisi dan kualitas } \\
\text { jaringan jalan }\end{array}$ & - & $\begin{array}{l}\text { Baik } \\
\text { Buruk }\end{array}$ & $\begin{array}{l}\text { Ruas jalan tidak } \\
\text { berlubang } \\
\text { Ruas jalan } \\
\text { berlubang }\end{array}$ & $\begin{array}{l}\text { Ada tidaknya hambatan pada jaringan } \\
\text { jalan di kawasan studi }\end{array}$ \\
\hline $\begin{array}{l}\text { Ketersediaan moda } \\
\text { transportasi publik } \\
\text { Jarak tempuh }\end{array}$ & - & - & - & $\begin{array}{c}\text { Banyaknya kesempatan masyarakat } \\
\text { dalam memilih moda transportasi publik } \\
\text { Panjang perjalanan yang dilakukan } \\
\text { masyarakat untuk mengakses tempat } \\
\text { tujuan }\end{array}$ \\
\hline Waktu tempuh & - & - & - & $\begin{array}{c}\text { Banyak waktu yang dibutuhkan } \\
\text { masyarakat untuk mengakses tempat } \\
\text { tujuan }\end{array}$ \\
\hline Biaya transportasi & - & - & - & $\begin{array}{c}\text { Banyak biaya yang dikeluarkan } \\
\text { masyarakat perhari dalam mengakses } \\
\text { tempat tujuan }\end{array}$ \\
\hline Pergerakan individu & $\begin{array}{l}\text { Tujuan pergerakan } \\
\text { Aktivitas yang dilakukan } \\
\text { di tempat tujuan }\end{array}$ & $\begin{array}{l}\text { Proporsi: } \\
\text { - utara } \\
\text { - selatan } \\
\text { - luar wilayah } \\
\text { Proporsi: } \\
\text { - belanja } \\
\text { - bekerja } \\
\text { - bersekolah }\end{array}$ & - & $\begin{array}{l}\text { Banyaknya perjalanan yang dilakukan } \\
\text { masyarakat ke kawasan studi }\end{array}$ \\
\hline
\end{tabular}

Sumber: Elaborasi dari Tamim (2000), Adisasmita (2015), Miro \& Hardani (2005), Fotini (2017), Martens (2012), Kartikasari (2017) 
Penelitian ini dilakukan dalam tiga analisis, yaitu analisis pola guna lahan, kondisi jaringan jalan, dan analisis komparasi. Analisis pola guna lahan melalui GIS membutuhkan data sekunder berupa data guna lahan dari BAPPPEDA Kota Surakarta. Sedangkan untuk analisis kondisi jaringan jalan, data yang dibutuhkan adalah data primer hasil observasi. Analisis komparasi menggunakan teknik sampling berupa accidental sampling. Dilakukan uji independent $t$ dengan tingkat kepercayaan $90 \%$ melalui SPSS dalam analisis komparasi. Selanjutnya, dilakukan perbandingan aksesibilitas dengan menyandingkan hasil analisis pola guna lahan dan jaringan jalan dengan hasil analisis komparasi. Berikut merupakan kerangka analisis penelitian yang dapat dilihat pada Gambar 1.

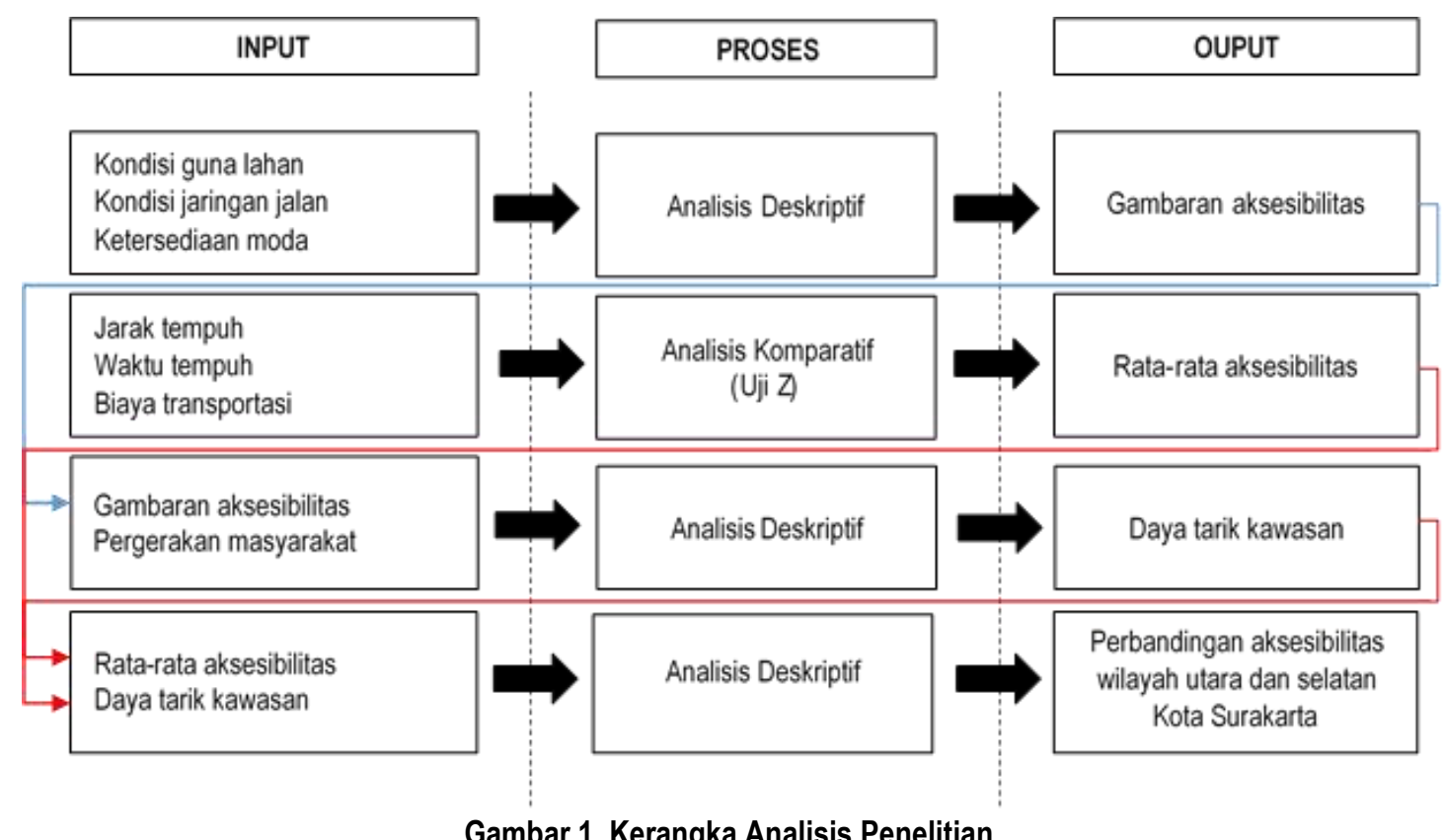

\section{HASIL DAN PEMBAHASAN}

\subsection{GAMBARAN AKSESIBILITAS WILAYAH UTARA DAN SELATAN KOTA SURAKARTA}

Kawasan SPK III (utara) memiliki proporsi guna lahan terbangun sebesar 88\% dan guna lahan non terbangun sebesar $12 \%$. Penggunaan lahan terbangun dominan berada di Kelurahan Nusukan dan Kadipiro, sedangkan penggunaan lahan non terbangun dominan berada di Kelurahan Banyuanyar. Guna lahan terbangun di kawasan didominasi permukiman dengan proporsi sebesar $91 \%$, diikuti perdagangan jasa sebesar $5 \%$, perkantoran sebesar $3 \%$, dan industri sebesar $1 \%$ yang dapat dilihat lebih detail pada Tabel 3.

Tabel 3. Luas Lahan Terbangun SPK III (Utara)

\begin{tabular}{clcccc}
\hline No. & Kelurahan & Permukiman $(\mathrm{Ha})$ & Jasa $(\mathrm{Ha})$ & Perkantoran $(\mathrm{Ha})$ & Industri (Ha) \\
\hline 1. & Banyuanyar & 65.94 & 4.46 & 0.95 & 1.14 \\
2. & Kadipiro & 369.93 & 12.42 & 8.16 & 8.55 \\
3. & Nusukan & 143.32 & 17.42 & 13.52 & 1.12 \\
4. & Sumber & 96.78 & 6.60 & 1.15 & 0,30 \\
& Total & $\mathbf{7 6 8 . 0 4}$ & $\mathbf{4 0 . 9 0}$ & $\mathbf{2 3 , 7 8}$ & $\mathbf{1 1 . 1 1}$ \\
& Persentase & $\mathbf{9 1 \%}$ & $\mathbf{5 \%}$ & $\mathbf{3 \%}$ & $\mathbf{1 \%}$ \\
\hline
\end{tabular}

Sumber: Badan Pusat Statistik (2019a)

Untuk guna lahan dengan aktivitas perdagangan jasa dan perkantoran masih berpusat di bagian selatan SPK III (utara) atau Kelurahan Nusukan. Sedangkan untuk guna lahan dengan aktivitas industri terluas di wilayah utara berada di Kelurahan Kadipiro. Pola guna lahan dengan aktivitas perdagangan jasa masih mengikuti pola jaringan jalan terutama jalan kolektor. 
Detail penggunaan lahan di SPK III (utara) dapat dilihat pada Gambar 2. Hal ini sesuai dengan pendapat Samli (2012) yang mengatakan pola aksesibilitas dan pola jaringan jalan mempengaruhi pola penggunaan lahan.

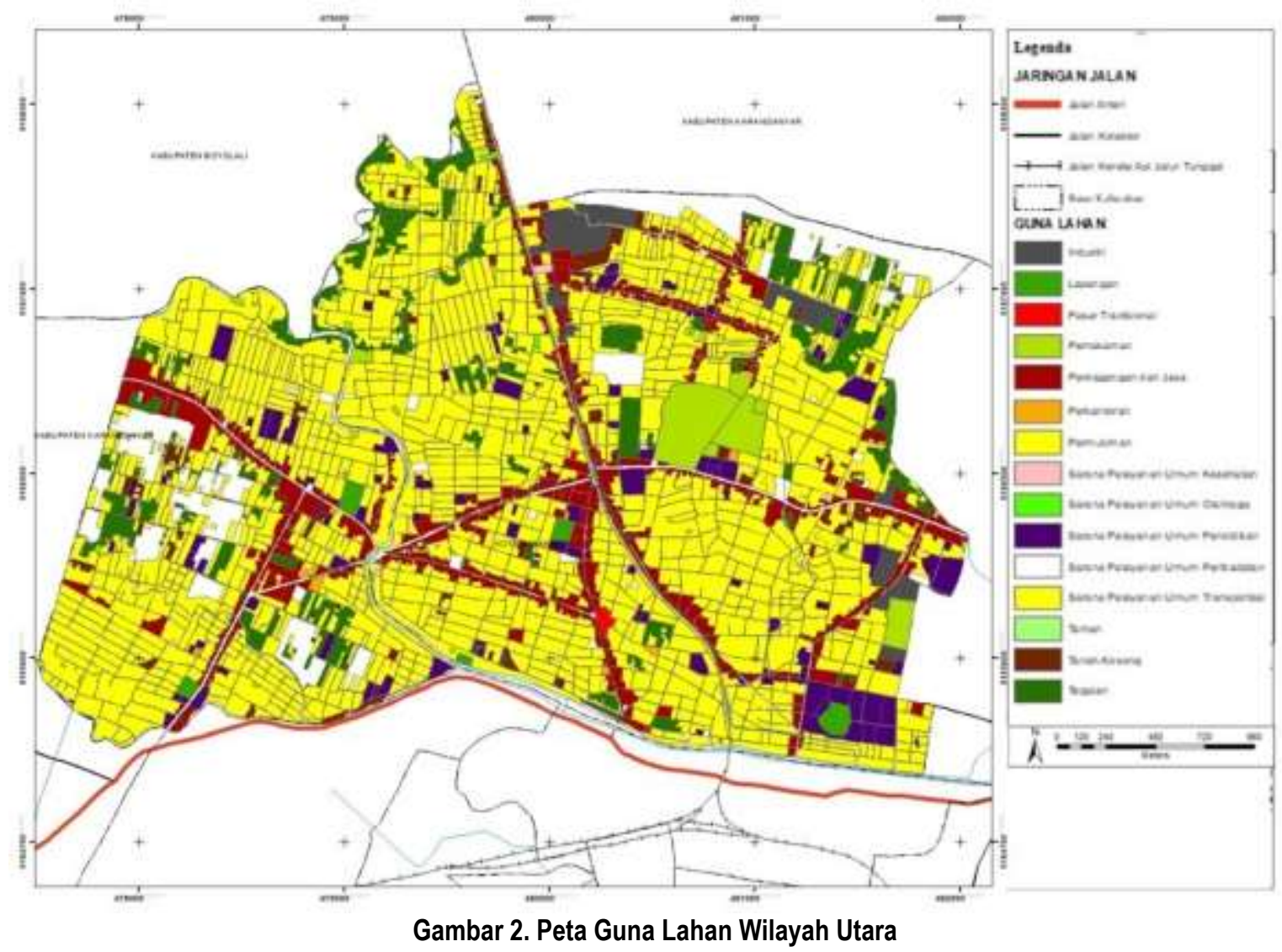

Guna lahan terbangun di Kawasan SPK I (selatan) mencapai 98\% yang berarti hampir seluruh wilayah selatan terdiri dari lahan terbangun. Pola guna lahan non terbangun di wilayah selatan hanya sebesar $2 \%$ dengan letak di sepanjang Sungai Bengawan Solo dan anak sungai seperti pada Gambar 3. Proporsi guna lahan terbangun di wilayah selatan tidak jauh berbeda dengan wilayah utara yang terdiri dari guna lahan untuk permukiman sebesar $79 \%$, diikuti dengan guna lahan untuk perkantoran sebesar $9 \%$, perdagangan jasa sebesar $9 \%$, dan industri sebesar $3 \%$. Untuk detail luas penggunaan lahan terbangun dapat dilihat pada Tabel 4.

Tabel 4. Luas Lahan Terbangun SPK I (Selatan)

\begin{tabular}{clcccc}
\hline No. & Kelurahan & Permukiman $(\mathrm{Ha})$ & Jasa $(\mathrm{Ha})$ & Perkantoran $(\mathrm{Ha})$ & Industri $(\mathrm{Ha})$ \\
\hline 1. & Gandekan & 28.56 & 1.44 & 1.40 & 0.00 \\
2. & Sewu & 29.79 & 2.45 & 1.16 & 1.73 \\
3. & Panularan & 42.23 & 7.70 & 2.61 & 0.90 \\
4. & Sriwedari & 38.44 & 7.78 & 5.97 & 1.41 \\
5. & Penumping & 32.24 & 9.52 & 6.23 & 1.41 \\
6. & Joyosuran & 28.87 & 2.50 & 6.11 & 1.40 \\
7. & Semanggi & 126.11 & 9.24 & 3.73 & 4.72 \\
8. & Pasar Kliwon & 16.88 & 2.30 & 3.22 & 2.57 \\
9. & Baluwarti & 33.85 & 1.85 & 0.00 & 0.00 \\
10. & Gajahan & 19.25 & 0.85 & 7.56 & 0.00 \\
11. & Kauman & 11.00 & 4.63 & 2.87 & 0.00 \\
12. & Kedung Lumbu & 29.89 & 3.63 & 7.30 & 0.92 \\
13. & Sangkrah & 33.00 & 1.82 & 4.03 & 0.00 \\
14. & Joyotakan & 30.75 & 2.15 & 1.75 & 2.68 \\
\hline
\end{tabular}




\begin{tabular}{clcccc}
\hline No. & Kelurahan & Permukiman $(\mathrm{Ha})$ & Jasa $(\mathrm{Ha})$ & Perkantoran $(\mathrm{Ha})$ & Industri $(\mathrm{Ha})$ \\
\hline 15. & Danukusuman & 34.40 & 4.19 & 6.15 & 1.70 \\
16. & Serengan & 56.14 & 4.28 & 1.95 & 1.13 \\
17. & Tipes & 42.39 & 5.18 & 2.22 & 3.20 \\
18. & Kratonan & 25.62 & 2.40 & 3.21 & 0.53 \\
19. & Jayengan & 13.51 & 2.17 & 8.65 & 1.09 \\
20. & Kemlayan & 22.15 & 1.30 & 7.61 & 1.13 \\
& Total & $\mathbf{6 9 5 . 0 7}$ & $\mathbf{7 7 . 3 8}$ & $\mathbf{8 3 . 7 3}$ & $\mathbf{2 6 . 5 2}$ \\
& Persentase & $\mathbf{7 9 \%}$ & $\mathbf{9 \%}$ & $\mathbf{9 \%}$ & $\mathbf{3 \%}$ \\
\hline
\end{tabular}

Sumber: Elaborasi dari Badan Pusat Statistik (2019b, 2019c, 2019d, 2019e)

Dapat dilihat pada Tabel 4 dan Gambar 3 bahwa selisih luas guna lahan dengan aktivitas perdagangan jasa dan perkantoran antarkelurahan rendah, tidak terdapat kelurahan yang mendominasi, seperti di wilayah utara. Pola perdagangan jasa di wilayah selatan sama dengan pola perdagangan jasa di wilayah utara yang mengikuti pola jaringan jalan. Akan tetapi, pola jaringan jalan yang mempengaruhi guna lahan perdagangan jasa di wilayah selatan tidak terbatas hanya pada jalan kolektor. Bila guna lahan dengan aktivitas perdagangan jasa di wilayah utara mengikuti jaringan jalan kolektor, pola guna lahan perdagangan jasa di wilayah selatan mengikuti pola jaringan jalan koletor dan lokal.

Berdasarkan hasil analisis GIS, diketahui bahwa pola guna lahan di wilayah utara acak dengan nilai indeks tetangga terdekat mencapai 1. Sedangkan untuk pola guna lahan di wilayah selatan membentuk pola mengelompok dengan nilai indeks tetangga terdekat sebesar 0,97 . Di samping itu, persentase luas guna lahan di wilayah utara untuk permukiman mencapai $91 \%$, perdagangan jasa sebesar $5 \%$, perkantoran sebesar $3 \%$, dan industri sebesar $1 \%$. Berbeda dengan persentase luas guna lahan di wilayah selatan yang terdiri dari $76 \%$ guna lahan permukiman, $9 \%$ perdagangan jasa, $9 \%$ perkantoran, dan $3 \%$ industri. Bila diperhatikan, terdapat selisih sebesar $2 \%$ untuk luas guna lahan perdagangan jasa (40.90 $\mathrm{Ha}$ ) dengan perkantoran $(23,78 \mathrm{Ha})$ di wilayah utara. Sedangkan luas guna lahan perdagangan jasa $(77.38 \mathrm{Ha})$ dengan perkantoran (83.73 $\mathrm{Ha}$ ) di wilayah selatan memiliki besar persentase yang sama, yaitu $9 \%$. Dalam kasus ini, guna lahan perdagangan jasa dan perkantoran di wilayah selatan dapat menampung lebih banyak aktivitas belanja dan bekerja dibandingkan wilayah utara.

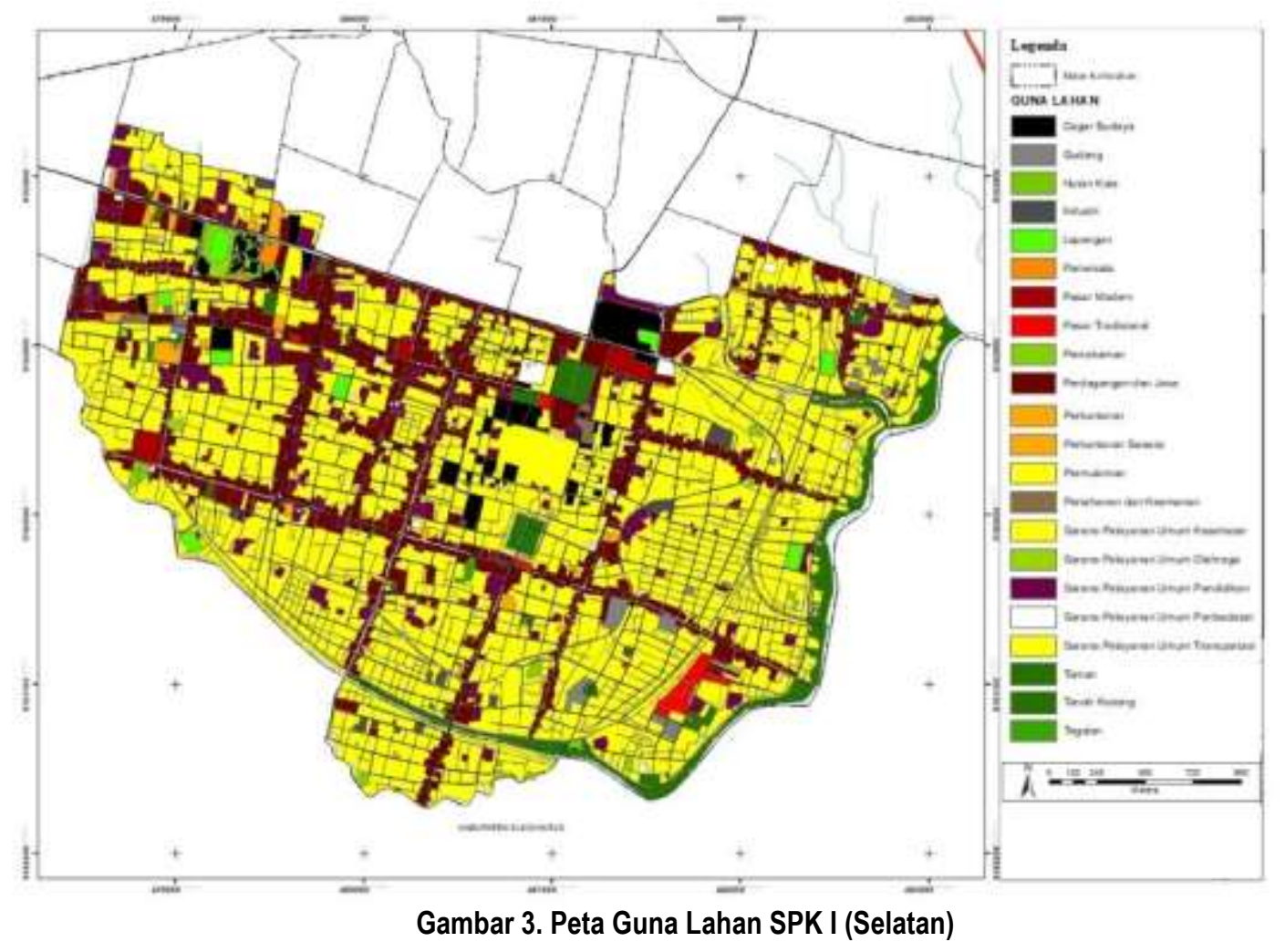


Kualitas jaringan jalan di SPK III (utara) tinggi dengan proporsi jaringan jalan dalam keadaan rusak sebesar 4\% dan 96\% dalam keadaan baik menurut observasi di lapangan. Terdapat 1 ruas dari 25 ruas jaringan jalan yang rusak di wilayah utara yang terletak di jalan lokal. Detail letak ruas jalan rusak dapat dilihat pada Gambar 4. Berdasarkan hasil kuesioner diketahui bahwa $84 \%$ responden berpendapat jaringan jalan di wilayah utara dalam kondisi baik, $14 \%$ responden berpendapat kondisi jalan buruk, dan $2 \%$ responden tidak menjawab. Dari $14 \%$ responden sebesar $57 \%$ berpendapat jaringan jalan dalam kondisi buruk ketika jalan berlubang, 29\% berpendapat kondisi jaringan jalan buruk karena mengalami kemacetan, dan 14\% berpendapat jaringan jalan buruk karena tidak terdapat trotoar serta jalan sempit.

Terdapat perbedaan sebesar $12 \%$ pada kondisi jalan baik dan 10\% pada kondisi jalan buruk. Perbedaan hasil antara pengamatan langsung dengan pendapat masyarakat disebabkan perbedaan gambaran mengenai jaringan jalan dalam kondisi buruk. Berdasarkan pengamatan langsung di lapangan kondisi jaringan jalan buruk digambarkan dengan jalan yang berlubang, sedangkan masyarakat berpendapat jaringan jalan dengan kondisi buruk diwakili oleh kondisi jalan berlubang, macet, dan jalan yang tidak memiliki trotoar serta sempit.

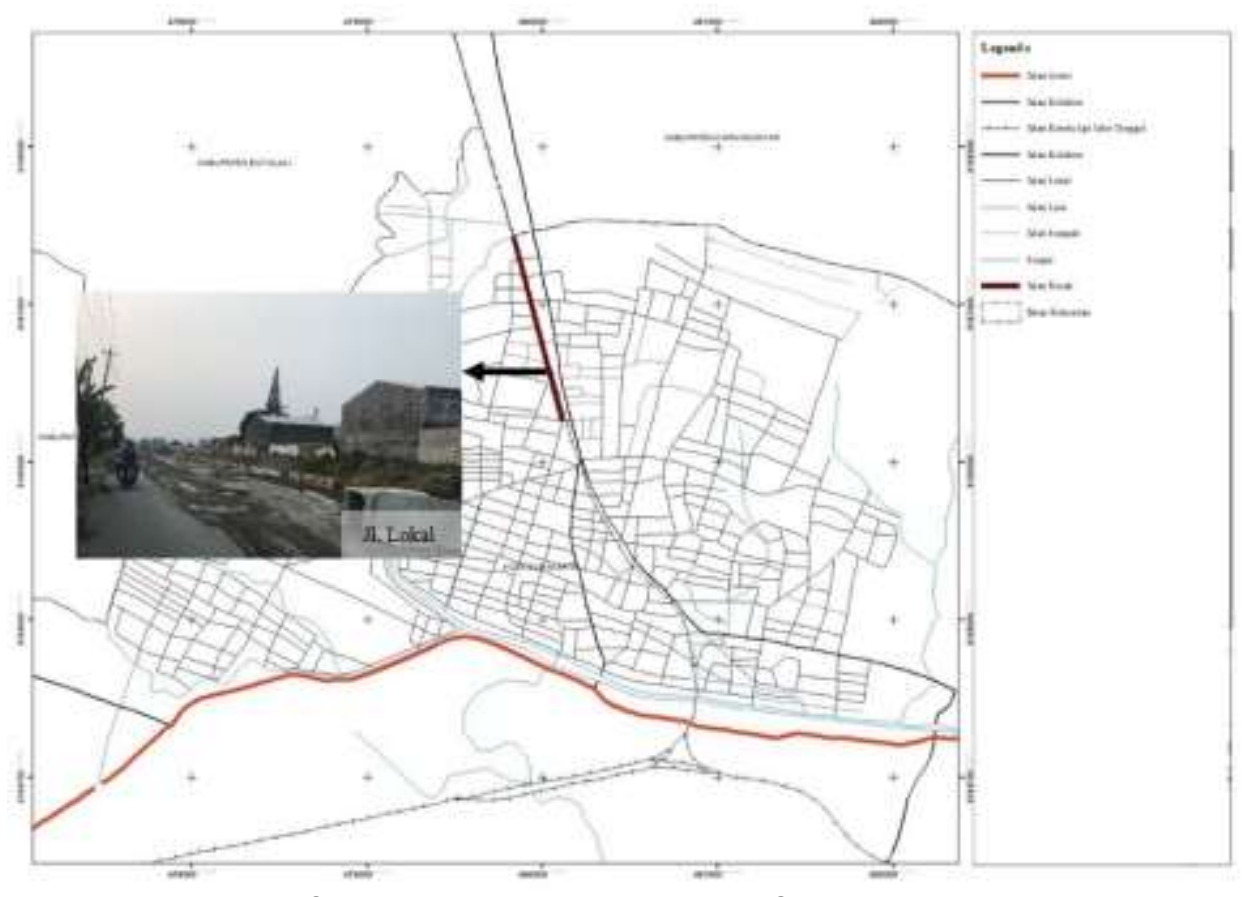

Gambar 4. Kondisi Jaringan Jalan SPK III (Utara)

Proporsi kualitas jaringan jalan di SPK I (selatan) dalam keadaan rusak sebesar $18 \%$ dan $82 \%$ dalam keadaan baik menurut observasi di lapangan. Terdapat 6 ruas dari 40 ruas jaringan jalan yang rusak di wilayah utara yang terletak di Jalan Ardedadali IV, Jalan Kahar Muzakan, Jalan Kom. Yos Sudarso, Jalan Kyai Mojo, Jalan Reksoniten, dan Jalan Veteran. Detail letak ruas jalan rusak dapat dilihat pada Gambar 5.

Bila dilihat dari hasil kuesioner, sebesar $80 \%$ responden berpendapat jaringan jalan di wilayah selatan dalam kondisi baik dan 20\% responden berpendapat kondisi jalan buruk. Dari 20\% responden sebesar 50\% berpendapat jaringan jalan buruk ketika jalan mengalami kemacetan, $45 \%$ berpendapat kondisi jaringan jalan buruk karena jalan berlubang, dan $5 \%$ berpendapat jaringan jalan buruk bila jalan tidak rata. Terdapat perbedaan antara hasil pengamatan langsung dengan pendapat masyarakat sebesar $2 \%$. Perbedaan terjadi karena gambaran yang mewakili kondisi jaringan jalan buruk dari hasil kuesioner lebih bervariasi, seperti kemacetan, jalan berlubang, dan tidak rata. 


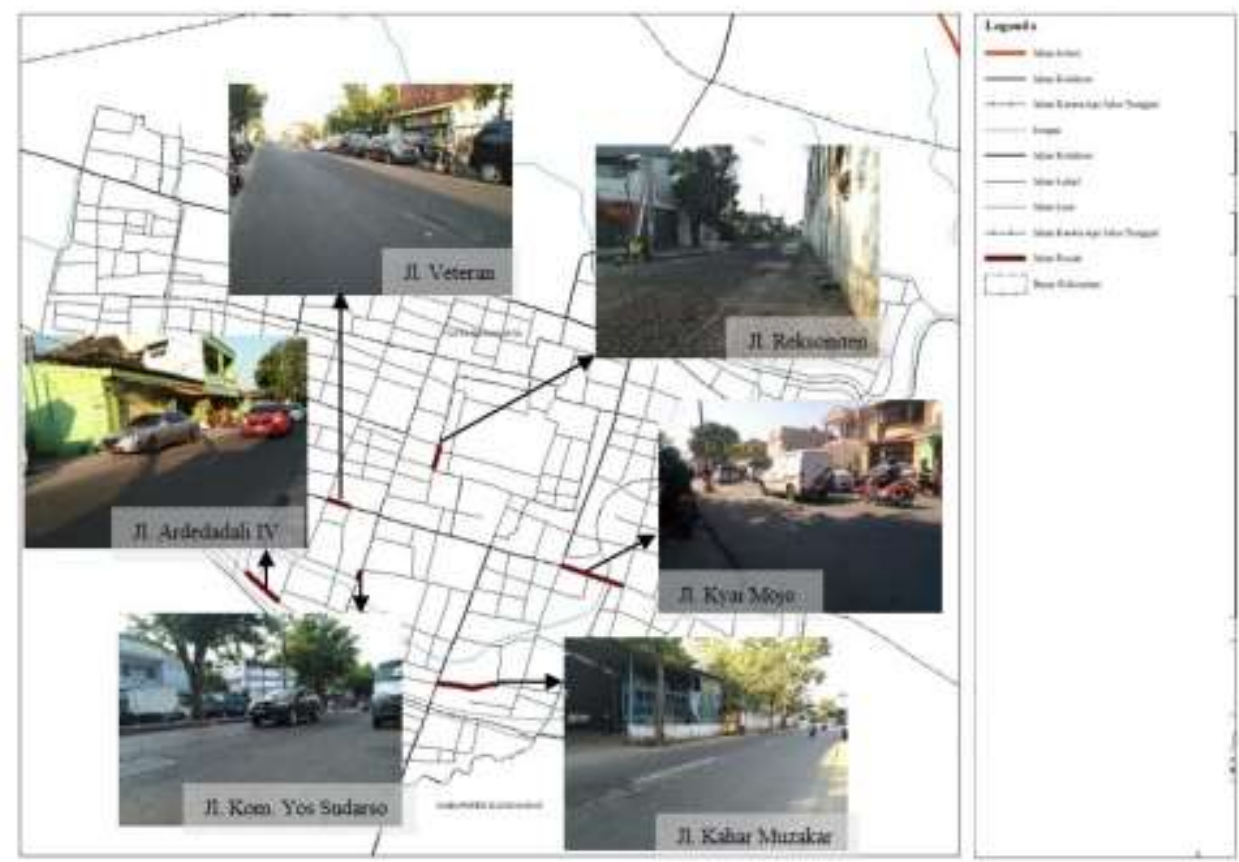

Gambar 5. Kondisi Jaringan Jalan SPK I (Selatan)

Moda transportasi publik yang melayani wilayah penelitian adalah Batik Solo Trans (BST). BST dengan rute pelayanan yang melayani wilayah utara di antaranya, koridor 4 , koridor 5 , koridor 6 , koridor 8 , koridor 9 , koridor 11 , koridor 13 dan koridor 15. Dari 7 koridor, 5 koridor melayani rute hingga luar Kota Surakarta dan 3 koridor menghubungkan wilayah utara dengan wilayah selatan. Koridor yang menghubungkan wilayah utara dengan wilayah selatan adalah koridor 6 , koridor 9 dan koridor 11. Pelayanan transportasi publik di wilayah utara menggunakan feeder BST. Untuk detail rute pelayanan feeder BST yang melayani wilayah utara dapat dilihat pada Gambar 6.

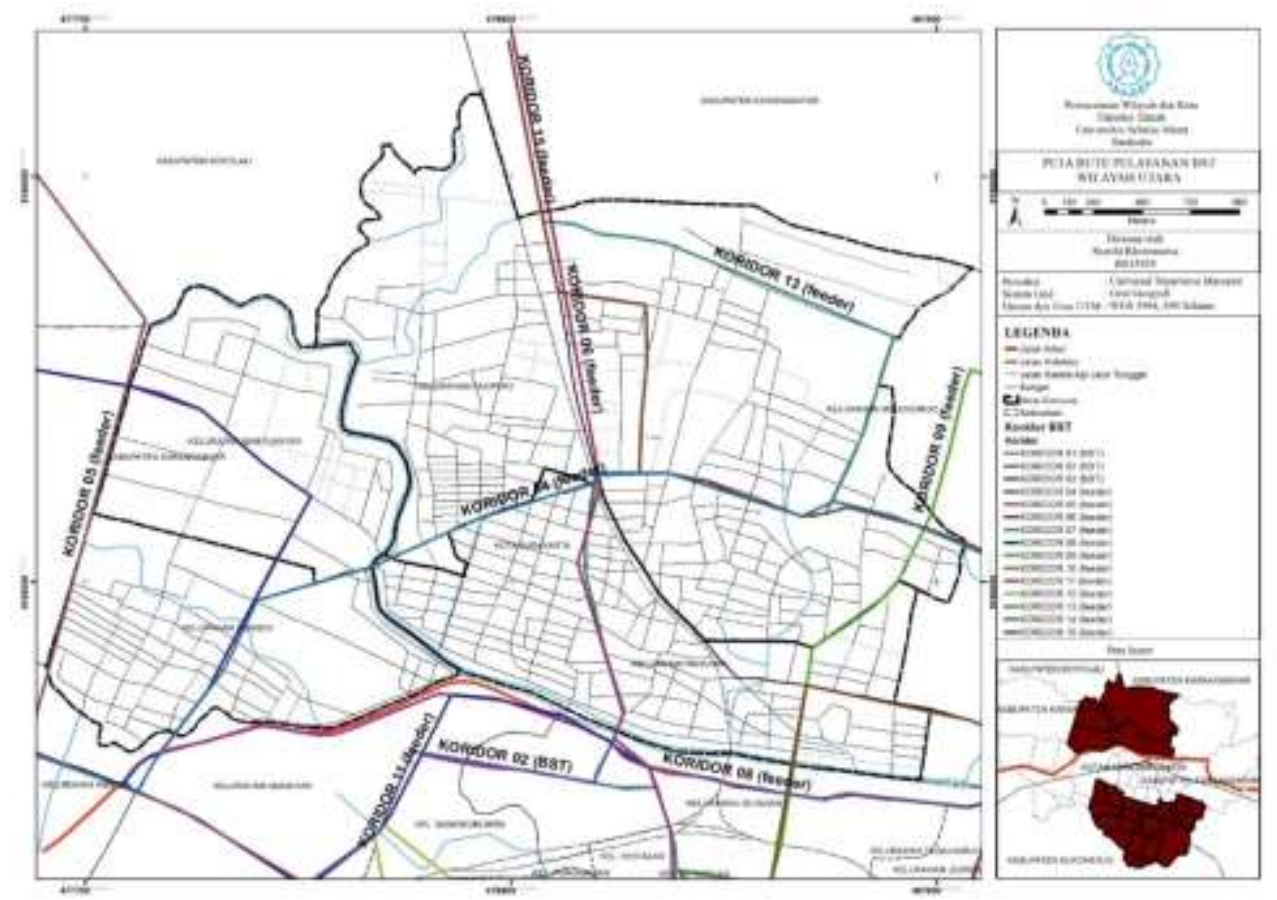

Gambar 6. Peta Rute Pelayanan Batik Solo Trans Wilayah Utara 
Untuk wilayah selatan, rute pelayanan transportasi publik Batik Solo Trans mencapai 12 rute dari 15 rute pelayanan transportasi publik di Kota Surakarta. Dari 12 rute terdapat 3 rute yang menghubungkan wilayah selatan dengan utara, seperti yang telah dijelaskan sebelumnya, yaitu koridor 6, koridor 9, dan koridor 11 dengan titik temu di Pasar Klewer. Moda transportasi publik yang melayani wilayah selatan berupa bus rapid transit dan feeder BST. Rute pelayanan BST yang melayani wilayah selatan menghubungkan lebih banyak guna lahan, seperti yang dapat dilihat pada Gambar 7. Hal ini menunjukkan bahwa keberadaan transportasi publik di wilayah selatan lebih memfasilitasi konektivitas antarguna lahan dibandingkan transportasi publik yang melayani wilayah utara.

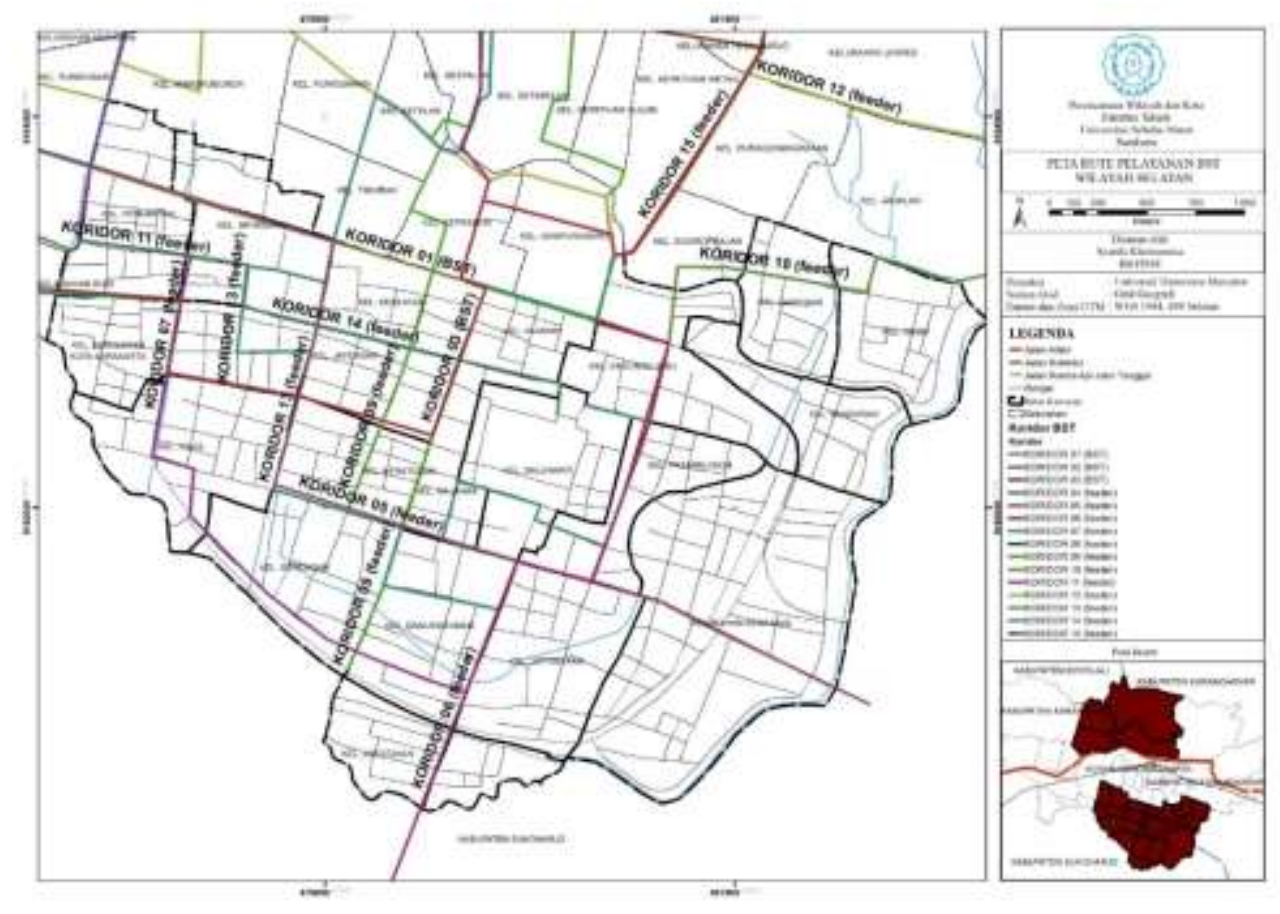

Gambar 7. Peta Rute Pelayanan Batik Solo Trans Wilayah Selatan

\subsection{ANALISIS KOMPARASI}

Berdasarkan hasil analisis komparasi jarak tempuh diketahui perbedaan rata-rata jarak tempuh antara wilayah utara dengan wilayah selatan Kota Surakarta sebesar $1 \mathrm{~km}$. Pada Tabel 5 dapat dilihat bahwa rata-rata jarak tempuh wilayah utara lebih besar daripada rata-rata jarak tempuh wilayah selatan. Hal ini menunjukkan bahwa jarak yang harus ditempuh masyarakat utara ketika melakukan kegiatan bekerja, belanja, dan sekolah lebih panjang dibandingkan masyarakat selatan. Perbedaan jarak tempuh menunjukkan adanya pengaruh pola guna lahan di wilayah utara yang masih terkonsentrasi di satu bagian wilayah. Penggunaan lahan yang masih didominasi satu jenis di satu bagian wilayah ini memunculkan perbedaan jarak tempuh antar masyarakat utara dalam mengakses guna lahan di lokasi yang sama.

Tabel 5. Analisis Komparasi Jarak Tempuh Wilayah Utara dan Selatan

\begin{tabular}{llccrr}
\multicolumn{6}{c}{ Group Statistics } \\
\hline \multirow{2}{*}{ Jarak Tempuh } & Kawasan & N & Mean & Std. Deviation & \multicolumn{1}{c}{ Std. Error Mean } \\
& Utara & 100 & 3.6496 & 3.86283 & .38628 \\
& Selatan & 100 & 2.6560 & 2.54492 & .25449 \\
\hline
\end{tabular}

Berdasarkan uji z seperti yang tertera pada Tabel 6 , diketahui bahwa variansi data jarak tempuh tidak sama dengan hasil $\mathrm{H} 0$ diterima. $\mathrm{H} 0$ ditolak dan $\mathrm{H} 1$ diterima yang berarti terdapat perbedaan rata-rata dari jarak tempuh yang bermakna secara signifikan karena nilai $p$ value $(0,033)<$ tingkat signifikansi $(0,05)$ dan t-hitung $(2,148)>t$-tabel $(1,960)$. Maka dengan diterimanya $\mathrm{H} 1$, jarak tempuh signifikan dalam menilai perbedaan aksesibilitas. 
Tabel 6. Hasil Uji Z Jarak Tempuh Independent Samples Test

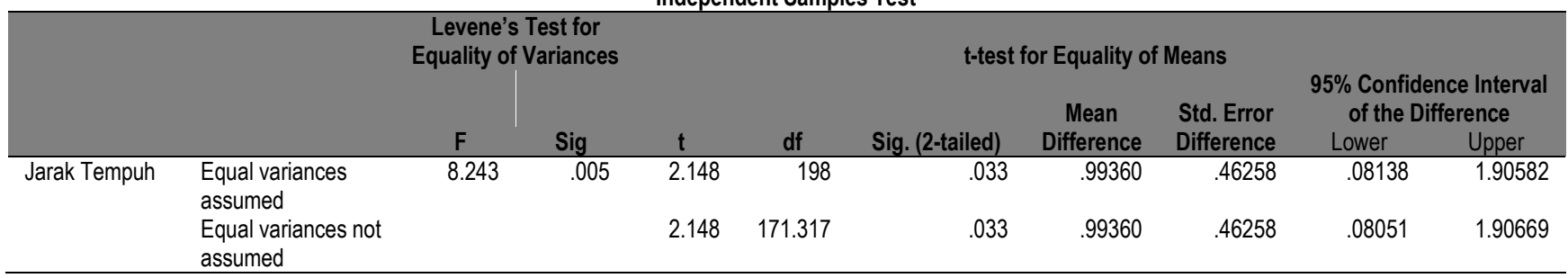

Berdasarkan hasil analisis komparasi waktu tempuh diketahui perbedaan rata-rata antara wilayah utara dengan wilayah selatan Kota Surakarta sebesar 1,54 menit. Pada Tabel 7, dapat dilihat bahwa rata-rata waktu tempuh wilayah selatan lebih besar daripada rata-rata jarak tempuh wilayah utara. Hal ini menunjukkan bahwa masyarakat selatan membutuhkan lebih banyak waktu menuju tempat beraktivitas. Perbedaan waktu tempuh menunjukkan adanya pengaruh kualitas dan kondisi jaringan jalan di wilayah selatan. Keberadaan kualitas dan kondisi jaringan jalan di wilayah selatan yang lebih buruk dibandingkan wilayah utara menyebabkan waktu yang ditempuh masyarakat selatan lebih lama dalam mencapai guna lahan berbeda.

Tabel 7. Analisis Komparasi Waktu Tempuh Wilayah Utara dan Selatan Group Statistics

\begin{tabular}{llrrrr} 
& Kawasan & N & Mean & Std. Deviation & Std. Error Mean \\
\hline \multirow{2}{*}{ Waktu Tempuh } & Utara & 100 & 11.75 & 8.789 & .879 \\
& Selatan & 100 & 13.29 & 8.242 & .824 \\
\hline
\end{tabular}

Dalam uji independent $t$ diketahui bahwa variansi data waktu tempuh sama dengan hasil $\mathrm{HO}$ diterima. Pada Tabel 8 , dapat diketahui bahwa $\mathrm{H} 0$ diterima dan $\mathrm{H} 1$ ditolak yang berarti tidak terdapat perbedaan rata-rata dari waktu tempuh yang bermakna secara signifikan karena nilai $p$ value $(0,203)>$ tingkat signifikansi $(0,05)$ dan t-hitung $(-1,278)<$ t-tabel $(1,960)$. Maka dengan diterimanya $\mathrm{HO}$, waktu tempuh tidak signifikan dalam menilai perbedaan aksesibilitas.

Tabel 8. Hasil Uji Z Waktu Tempuh Independent Samples Test

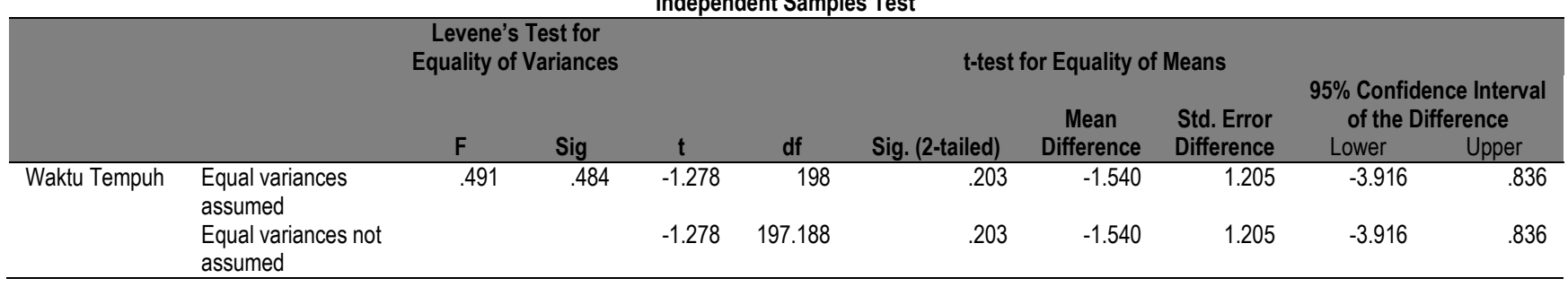

Berdasarkan hasil analisis komparasi biaya transportasi diketahui perbedaan rata-rata antara wilayah utara dengan wilayah selatan Kota Surakarta sebesar Rp 460,00. Pada Tabel 9, dapat dilihat bahwa rata-rata biaya transportasi wilayah utara lebih besar daripada rata-rata wilayah selatan. Hal ini menunjukkan bahwa masyarakat utara mengeluarkan ongkos lebih banyak untuk melakukan perjalanan dibandingkan masyarakat selatan. Perbedaan biaya transportasi harian menunjukkan adanya pengaruh keberadaan transportasi publik di wilayah utara. Minimnya rute transportasi publik di wilayah utara menyebabkan masyarakat utara memilih kendaraan lain yang dapat digunakan untuk mencapai tujuan sehingga masyarakat utara mengeluarkan biaya transportasi harian lebih banyak dibandingkan masyarakat selatan.

Tabel 9. Analisis Komparasi Biaya Transportasi Wilayah Utara dan Selatan Group Statistics

\begin{tabular}{llrrrr} 
& Kawasan & N & \multicolumn{1}{c}{ Mean } & Std. Deviation & Std. Error Mean \\
\hline \multirow{2}{*}{ Biaya Perjalanan } & Utara & 100 & 6.06 & 5.512 & .551 \\
& Selatan & 100 & 5.60 & 4.677 & .468 \\
\hline
\end{tabular}

Dalam uji independent $t$ diketahui bahwa variansi data biaya transportasi tidak sama dengan hasil $\mathrm{H} 0$ diterima. Pada Tabel 10, diketahui bahwa $\mathrm{H} 0$ diterima dan $\mathrm{H} 1$ ditolak berarti tidak terdapat perbedaan secara signifikan karena nilai $p$ value $(0,525)$ 
$>$ tingkat signifikansi $(0,05)$ dan t-hitung $(0,636)<\mathrm{t}$-tabel $(1,645)$. Maka dengan diterimanya $\mathrm{H} 0$, biaya transportasi tidak signifikan dalam menilai perbedaan aksesibilitas.

Tabel 10. Hasil Uji Z Biaya Transportasi

Independent Samples Test

\begin{tabular}{|c|c|c|c|c|c|c|c|c|c|c|}
\hline & & \multicolumn{2}{|c|}{$\begin{array}{l}\text { Levene's Test for } \\
\text { Equality of Variances }\end{array}$} & \multirow{2}{*}{\multicolumn{5}{|c|}{ t-test for Equality of Means }} & \multirow{2}{*}{\multicolumn{2}{|c|}{$\begin{array}{l}95 \% \text { Confidence Interval } \\
\text { of the Difference }\end{array}$}} \\
\hline & & & & & & & Mean & Std. Error & & \\
\hline & & $\mathrm{F}$ & Sig & $\mathrm{t}$ & df & Sig. (2-tailed) & Difference & Difference & Lower & Upper \\
\hline \multirow[t]{2}{*}{$\begin{array}{l}\text { Biaya } \\
\text { Perjalanan }\end{array}$} & $\begin{array}{l}\text { Equal variances } \\
\text { assumed }\end{array}$ & 5.824 & .017 & .636 & 198 & .525 & .460 & .723 & -.966 & 1.886 \\
\hline & $\begin{array}{l}\text { Equal variances not } \\
\text { assumed }\end{array}$ & & & .636 & 192.895 & .525 & .460 & .723 & -.966 & 1.886 \\
\hline
\end{tabular}

\subsection{DAYA TARIK KAWASAN}

Berdasarkan hasil olahan kuesioner, didapatkan informasi bahwa masyarakat utara cenderung melakukan perjalanan menuju wilayah selatan dan Kabupaten Boyolali untuk aktivitas belanja dan bekerja. Perjalanan menuju Kabupaten Karanganyar untuk aktivitas bekerja dan Kabupaten Sukoharjo menampung pergerakan masyarakat utara untuk aktivitas belanja, bekerja, serta bersekolah. Untuk Kota Surakarta menampung pergerakan masyarakat utara untuk aktivitas bekerja dan bersekolah.

Berdasarkan pergerakan masyarakat yang dijelaskan di atas dapat dilihat bahwa pergerakan masyarakat utara menyebar. Pergerakan masyarakat utara yang menyebar dan acak berbanding lurus dengan penggunaan lahan di utara yang masih didominasi permukiman dengan ketersediaan fasilitas perkotaan masih belum memadai. Bila dilihat dalam ruang lingkup wilayah studi, masyarakat utara melakukan perjalanan ke wilayah selatan, seperti yang dapat dilihat pada Gambar 8. Hal ini berarti bahwa wilayah selatan memiliki daya tarik kawasan yang tidak ada di wilayah utara. Daya tarik tersebut, seperti yang telah disebutkan, terkait dengan guna lahan di wilayah utara yang belum menampung seluruh aktivitas yang dibutuhkan oleh masyarakat.

Untuk wilayah selatan, masyarakat melakukan perjalanan menuju Kabupaten Sukoharjo untuk aktivitas belanja, bekerja, dan bersekolah. Sedangkan pergerakan masyarakat selatan menuju Kota Surakarta untuk aktivitas bekerja dan bersekolah. Berbeda dengan wilayah utara, masyarakat di wilayah selatan tidak melakukan perjalanan menuju wilayah utara. Berdasarkan pergerakan masyarakat yang dijelaskan sebelumnya, dapat dilihat bahwa pergerakan masyarakat selatan terkonsentrasi dan merata di wilayah selatan. Hal ini menunjukkan wilayah selatan memiliki daya tarik kawasan dengan guna lahan yang mampu menampung aktivitas atau menyediakan kebutuhan masyarakat di wilayah selatan.

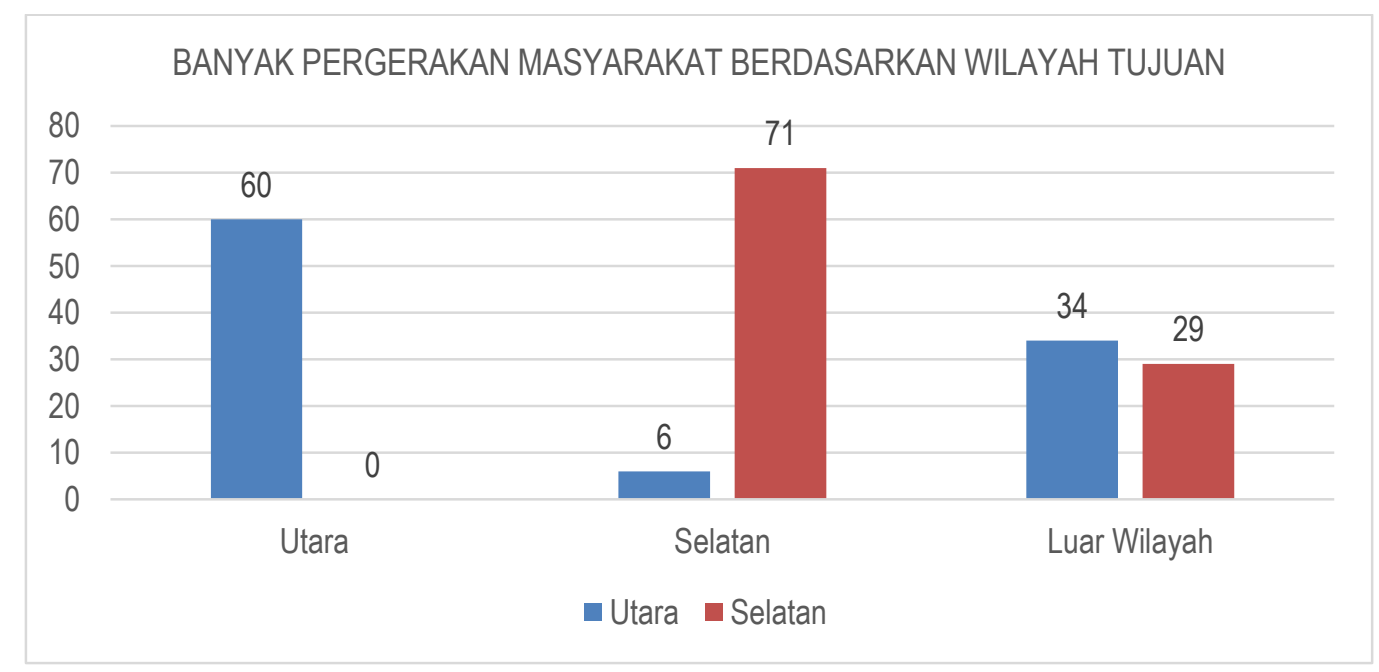

Gambar 8. Diagram Perbandingan Pergerakan Masyarakat Utara dan Selatan Kota Surakarta 
Pergerakan masyarakat utara menuju wilayah selatan untuk aktivitas bekerja sebanyak 3 orang dan belanja sebanyak 3 orang. Hal ini menunjukkan bahwa wilayah selatan mampu menarik pergerakan dari wilayah utara. Daya tarik wilayah selatan berasal dari tarikan guna lahan perdagangan jasa dan perkantoran serta kemudahan mengakses guna lahan.

Penggunaan lahan terbesar di wilayah utara beturut-turut berdasarkan GIS adalah permukiman, perdagangan jasa, dan tegalan. Berdasarkan penggunaan lahan terbesar yang ada, maka aktivitas masyarakat untuk belanja, bekerja, dan bersekolah tidak dapat tertampung seluruhnya. Sedangkan, kawasan dengan tingkat pergerakan tinggi atau wilayah selatan menarik pergerakan masyarakat dari utara untuk aktivitas belanja dan bekerja. Bila melihat penggunaan lahan terbesar di wilayah selatan berdasarkan GIS, secara beturut-turut adalah permukiman, perdagangan jasa, dan sarana pelayanan pendidikan.

Kemampuan wilayah selatan dalam menarik pergerakan masyarakat lebih baik dari wilayah utara. Kemampuan tarikan pergerakan yang lebih baik ini menunjukkan bahwa wilayah selatan memiliki guna lahan yang variatif dengan aksesibilitas yang baik. Pola guna lahan di wilayah selatan membentuk pola mengelompok. Selain itu, wilayah selatan didukung dengan ketersediaan transportasi publik berupa Batik Solo Trans (BST) yang menghubungkan seluruh blok guna lahan.

\subsection{PERBANDINGAN AKSESIBILITAS WILAYAH UTARA DAN SELATAN}

Berdasarkan analisis komparasi diketahui perbedaan rata-rata aksesibilitas antara wilayah utara dengan selatan yang memiliki selisih yang tidak signifikan (Tabel 11). Selain itu, variabel yang memiliki signifikansi terhadap aksesibilitas hanya jarak tempuh, sedangkan waktu tempuh dan biaya transportasi tidak dapat memperlihatkan perbedaan yang cukup signifikan dalam menilai aksesibilitas. Hasil yang didapatkan menunjukkan kemampuan individu dari wilayah utara lebih tinggi dibandingkan masyarakat selatan dalam mengakses suatu wilayah. Berdasarkan rata-rata jarak tempuh yang panjang dan biaya transportasi yang tinggi, masyarakat utara tetap melakukan perjalanan untuk memenuhi kebutuhannya dan melakukan aktivitas harian.

Namun, pada kemampuan fisik wilayah selatan memiliki daya tarik kawasan yang lebih baik. Daya tarik wilayah selatan terdapat pada pola guna lahan yang mengelompok dengan batas antar blok kawasan yang jelas. Adanya pola guna lahan yang mengelompok, maka jarak yang ditempuh semakin dekat. Hal ini sesuai dengan hasil analisis komparasi rata-rata jarak tempuh wilayah selatan yang pendek dibandingkan wilayah utara. Selain itu, keberadaan transportasi publik yang menghubungkan antarblok guna lahan di wilayah selatan mendukung pergerakan yang terjadi di kawasan. Tingkat pelayanan dari guna lahan di wilayah selatan lebih tinggi dibandingkan wilayah utara terutama pada guna lahan untuk perdagangan jasa. Keberadaan pola guna lahan yang mengelompok, transportasi publik, dan tingkat pelayanan guna lahan di kawasan mampu menarik pergerakan dari luar kawasan termasuk pergerakan dari utara. Kemampuan wilayah selatan dalam menarik pergerakan masih berkaitan dengan aksesibilitas di wilayah tersebut. Adanya daya tarik kawasan yang lebih tinggi maka dapat dikatakan bahwa aksesibilitas di wilayah selatan lebih baik dibandingkan aksesibilitas di wilayah utara.

\section{Tabel 11. Perbandingan Aksesibilitas Wilayah Berdasarkan Variabel Penelitian}

\begin{tabular}{|c|c|c|c|c|}
\hline No. & Komponen & Utara & Selatan & Elaborasi \\
\hline 1. & $\begin{array}{l}\text { Pola guna } \\
\text { lahan }\end{array}$ & $\begin{array}{l}\text { Penggunaan lahan yang } \\
\text { menyebar acak membuat blok } \\
\text { kawasan sulit dibedakan. }\end{array}$ & $\begin{array}{l}\text { Penggunaan lahan } \\
\text { mengelompok membuat blok } \\
\text { kawasan mudah dibedakan. }\end{array}$ & $\begin{array}{l}\text { Pola guna lahan mengelompok di } \\
\text { wilayah selatan menghasilkan } \\
\text { interaksi antarguna lahan yang } \\
\text { lebih tinggi dibandingkan guna } \\
\text { lahan yang tidak berpola di wilayah } \\
\text { utara. }\end{array}$ \\
\hline 2. & $\begin{array}{l}\text { Kondisi dan } \\
\text { kualitas } \\
\text { jaringan jalan }\end{array}$ & $\begin{array}{l}\text { Jaringan jalan menurut hasil } \\
\text { observasi } 92 \% \text { dalam kondisi baik } \\
\text { dan } 8 \% \text { dalam kondisi buruk. } \\
\text { Sedangkan, } 84 \% \text { masyarakat } \\
\text { menganggap kondisi jaringan } \\
\text { jalan baik dan } 16 \% \text { masyarakat } \\
\text { menganggap kondisi jaringan } \\
\text { jalan buruk. Perbedaan hasil } \\
\text { lapangan dengan kuesioner } \\
\text { karena kondisi jalan buruk }\end{array}$ & $\begin{array}{l}\text { Jaringan jalan dalam kondisi } \\
\text { baik sebesar } 88 \% \text { dan } 12 \% \\
\text { dalam kondisi buruk } \\
\text { berdasarkan hasil observasi. } \\
\text { Sedangkan, } 80 \% \text { masyarakat } \\
\text { menganggap kondisi jaringan } \\
\text { jalan baik dan } 20 \% \text { masyarakat } \\
\text { menganggap kondisi jaringan } \\
\text { jalan buruk. Perbedaan sebesar } \\
8 \% \text { karena lebih banyak }\end{array}$ & $\begin{array}{l}\text { Terdapat kesamaan hasil } \\
\text { perbandingan kondisi jalan buruk } \\
\text { dengan kondisi jalan baik pada } \\
\text { hasil observasi dengan kuesioner. } \\
\text { Kualitas jaringan jalan di wilayah } \\
\text { utara dan selatan termasuk ke } \\
\text { dalam persentase yang tinggi } \\
\text { sehingga mendukung aksesibilitas } \\
\text { di kedua wilayah. }\end{array}$ \\
\hline
\end{tabular}




\begin{tabular}{|c|c|c|c|c|}
\hline No. & Komponen & Utara & Selatan & Elaborasi \\
\hline & & $\begin{array}{l}\text { menurut masyarakat terbagi } \\
\text { menjadi jalan berlubang, } \\
\text { kemacetan, jalan sempit dan tidak } \\
\text { adanya trotoar. Berbeda dengan } \\
\text { hasil pengamatan di lapangan } \\
\text { yang hanya melihat pada tingkat } \\
\text { kerusakan jalan. }\end{array}$ & $\begin{array}{l}\text { pengelompokkan jalan dalam } \\
\text { kondisi buruk menurut } \\
\text { masyarakat, seperti kemacetan, } \\
\text { jalan berlubang dan jalan tidak } \\
\text { rata. Sedangkan pada hasil } \\
\text { pengamatan di lapangan, jalan } \\
\text { dengan kondisi buruk merujuk } \\
\text { pada jalan berlubang. }\end{array}$ & \\
\hline 3. & $\begin{array}{l}\text { Ketersediaan } \\
\text { moda } \\
\text { transportasi } \\
\text { publik }\end{array}$ & $\begin{array}{l}\text { Dilayani } 8 \text { rute transportasi publik } \\
\text { berupa feeder BST. Pelayanan } \\
\text { moda transportasi publik } \\
\text { mendukung guna lahan } \\
\text { perdagangan jasa, tapi tidak } \\
\text { terhubung dengan guna lahan } \\
\text { permukiman di kawasan. }\end{array}$ & $\begin{array}{l}\text { Dilayani } 12 \text { rute transportasi } \\
\text { publik berupa bus rapid transit } \\
\text { dan feeder BST. Pelayanan } \\
\text { moda transportasi publik } \\
\text { menghubungkan hampir seluruh } \\
\text { blok-blok guna lahan di } \\
\text { kawasan. }\end{array}$ & $\begin{array}{l}\text { Pelayanan moda transportasi publik } \\
\text { di wilayah utara belum optimal } \\
\text { dalam menghubungkan berbagai } \\
\text { guna lahan di kawasan. Berbeda } \\
\text { dengan wilayah selatan, } \\
\text { transportasi publik telah } \\
\text { memfasilitasi konektivitas } \\
\text { antarguna lahan di kawasan, } \\
\text { sehingga kemudahan interaksi } \\
\text { dengan moda transportasi publik } \\
\text { antarguna lahan lebih tinggi di } \\
\text { wilayah selatan. }\end{array}$ \\
\hline 4. & Jarak tempuh & $\begin{array}{l}\text { Rata-rata jarak tempuh } \\
\text { masyarakat yang mencapai 3,65 } \\
\text { km berkaitan dengan guna lahan } \\
\text { perdagangan jasa dan } \\
\text { perkantoran yang cenderung } \\
\text { memusat di bagian selatan } \\
\text { wilayah utara. }\end{array}$ & $\begin{array}{l}\text { Rata-rata jarak tempuh } \\
\text { masyarakat sebesar 2,65 km. } \\
\text { Hal itu karena pola guna lahan } \\
\text { mengelompok dan cenderung } \\
\text { lebih kompak di kawasan }\end{array}$ & $\begin{array}{l}\text { Jarak tempuh di wilayah utara } \\
\text { relatif panjang karena guna lahan } \\
\text { untuk perdagangan jasa dan } \\
\text { perkantoran yang masih memusat } \\
\text { di bagian selatan kawasan. } \\
\text { Berbeda dengan wilayah selatan } \\
\text { yang memiliki pola guna lahan } \\
\text { mengelompok sehingga jarak } \\
\text { tempuh relatif pendek. }\end{array}$ \\
\hline 5. & $\begin{array}{l}\text { Waktu } \\
\text { tempuh }\end{array}$ & $\begin{array}{l}\text { Rata-rata waktu tempuh } \\
\text { masyarakat sebesar } 11,75 \text { menit. } \\
\text { Tidak signifikan dalam melihat } \\
\text { aksesibilitas, tetapi mendukung } \\
\text { hasil analisis kondisi dan kualitas } \\
\text { jaringan jalan di kawasan. }\end{array}$ & $\begin{array}{l}\text { Rata-rata waktu tempuh } \\
\text { masyarakat sebesar } 13,29 \\
\text { menit. Hasil rata-rata ini } \\
\text { mendukung pendapat } \\
\text { masyarakat mengenai } \\
\text { kemacetan yang terjadi di } \\
\text { kawasan. }\end{array}$ & $\begin{array}{l}\text { Rata-rata waktu di kedua wilayah } \\
\text { dipengaruhi kualitas jaringan jalan. } \\
\text { Persentase kondisi jalan baik di } \\
\text { wilayah utara yang lebih tinggi dari } \\
\text { wilayah selatan menghasilkan rata- } \\
\text { rata waktu tempuh relatif singkat. }\end{array}$ \\
\hline 6. & $\begin{array}{l}\text { Biaya } \\
\text { transportasi } \\
\text { harian }\end{array}$ & $\begin{array}{l}\text { Rata-rata ongkos harian } \\
\text { masyarakat mencapai Rp } \\
6.060,00 \text {. Hal ini berkaitan } \\
\text { dengan jarak tempuh yang relatif } \\
\text { panjang. }\end{array}$ & $\begin{array}{l}\text { Rata-rata ongkos harian } \\
\text { masyarakat mencapai Rp } \\
5.600,00 \text {. Hasil tersebut } \\
\text { berkaitan dengan jarak tempuh } \\
\text { di kawasan yang relatif pendek. }\end{array}$ & $\begin{array}{l}\text { Biaya transportasi berkaitan } \\
\text { dengan jarak tempuh. Biaya } \\
\text { transportasi di wilayah utara relatif } \\
\text { tinggi karena jarak tempuh yang } \\
\text { panjang. Berbeda dengan wilayah } \\
\text { selatan yang memiliki rata-rata } \\
\text { biaya transportasi relatif rendah } \\
\text { karena jarak tempuh yang pendek. }\end{array}$ \\
\hline 7. & $\begin{array}{l}\text { Pergerakan } \\
\text { individu }\end{array}$ & $\begin{array}{l}\text { Pola pergerakan masyarakat } \\
\text { yang acak berbanding lurus } \\
\text { dengan pola sebaran } \\
\text { penggunaan lahan. Di samping } \\
\text { itu, masyarakat melakukan } \\
\text { perjalanan ke wilayah selatan } \\
\text { karena guna lahan perdagangan } \\
\text { jasa dan perkantoran di wilayah } \\
\text { utara belum dapat menampung } \\
\text { seluruh aktivitas belanja dan } \\
\text { bekerja masyarakat utara. }\end{array}$ & $\begin{array}{l}\text { Pola pergerakan masyarakat } \\
\text { yang menyebar rata di bagian } \\
\text { selatan dan tengah Kota } \\
\text { Surakarta karena pola sebaran } \\
\text { guna lahan yang mengolompok } \\
\text { di wilayah selatan. Wilayah } \\
\text { selatan merupakan wilayah } \\
\text { dengan pergerakan individu } \\
\text { paling tinggi. }\end{array}$ & $\begin{array}{l}\text { Interaksi guna lahan di wilayah } \\
\text { selatan yang lebih mudah karena } \\
\text { pola yang mengelompok serta } \\
\text { keberadaan transportasi publik } \\
\text { menyebabkan pergerakan di } \\
\text { kawasan juga lebih tinggi. } \\
\text { Pergerakan di wilayah utara } \\
\text { sehingga kualitas jaringan jalan di } \\
\text { wilayah selatan memiliki persentase } \\
\text { lebih rendah dari jaringan jalan di } \\
\text { wilayah utara. }\end{array}$ \\
\hline
\end{tabular}




\section{KESIMPULAN}

Dari hasil penelitian ini dapat disimpulkan bahwa wilayah selatan memiliki aksesibilitas tempat yang lebih baik dibandingkan wilayah utara. Kesenjangan perkembangan di kedua wilayah dilihat dari perkembangan wilayah melalui proporsi guna lahan terbangun di kedua wilayah yang didukung pada kemampuan wilayah dalam mengakomodasi pergerakan baik di dalam kawasan maupun dari luar kawasan. Banyaknya pergerakan di dalam dan menuju kawasan membuka peluang wilayah untuk berkembang. Pergerakan tersebut difasilitasi pola guna lahan yang mengelompok dengan jarak tempuh yang pendek dan rute pelayanan moda yang menghubungkan seluruh blok guna lahan hingga luar wilayah studi sehingga dapat mengurangi biaya transportasi yang harus dikeluarkan. Selain itu, pergerakan yang tinggi berkaitan dengan kualitas dan kondisi jaringan jalan di kawasan. Semakin tinggi pergerakan yang ada di kawasan, maka peluang kualitas jaringan jalan menurun dan jaringan jalan dalam kondisi yang buruk semakin besar. Perkembangan di wilayah utara yang lebih lambat dibandingkan wilayah selatan berkaitan dengan aksesibilitas di wilayah utara yang belum optimal.

\section{DAFTAR PUSTAKA}

Adisasmita, R. (2015). Analisis Kebutuhan Transportasi. Yogyakarta: Graha IImu.

Badan Pusat Statistik. (2018). Kota Surakarta dalam Angka Tahun 2018. Surakarta. Retrieved from https://surakartakota.bps.go.id/publication/2018/08/16/c3a56b56c074228d1b0e90e0/kotasurakarta-dalam-angka-2018.html

Badan Pusat Statistik. (2019a). Kecamatan Banjarsari Dalam Angka 2018. Surakarta. Retrieved from https://surakartakota.bps.go.id/publication/2018/09/26/d2a79aedf0d5cf64bade876a/kecamatan-banjarsari-dalam-angka-2018.html

Badan Pusat Statistik. (2019b). Kecamatan Jebres Dalam Angka 2018. Surakarta. Retrieved from https://surakartakota.bps.go.id/publication/2018/09/26/cb18094f58c445639ffd0fb1/kecamatan-jebres-dalam-angka-2018.html

Badan Pusat Statistik. (2019c). Kecamatan Laweyan Dalam Angka 2018. Surakarta. Retrieved from https://surakartakota.bps.go.id/publication/2018/09/26/ea91ca9b1cd7dcb1cbb0d212/kecamatan-laweyan-dalam-angka-2018.html

Badan Pusat Statistik. (2019d). Kecamatan Pasar Kliwon Dalam Angka 2018. Surakarta. Retrieved from https://surakartakota.bps.go.id/publication/2018/09/26/4916b8c92de2f3fdf9c081d4/kecamatan-pasar-kliwon-dalam-angka2018.html

Badan Pusat Statistik. (2019e). Kecamatan Serengan Dalam Angka 2018. Surakarta. Retrieved from https://surakartakota.bps.go.id/publication/2018/09/26/95f839639d3670e1a04d8f04/kecamatan-serengan-dalam-angka-2018.html

Fotini, M. (2017). A New Anthropocentric Approach in Accessibility Analysis: The Activity Space and The Accessibility Measures. Transportation Research Procedia, 24, 491-498. https://doi.org/10.1016/j.trpro.2017.05.088

Kartikasari, D., Sitorus, S. R. P., \& Soma, S. (2017). Analisis Jaringan Jalan dan Arahan Prioritas Penanganannya di Kabupaten Purworejo, Provinsi Jawa Tengah. MT - Agriculture, 2105. Retrieved from https://repository.ipb.ac.id/handle/123456789/85243

Kaza, N. (2015). Time Dependent Accessibility. Jurnal of Urban Management, 4(1), 24-39. https://doi.org/10.1016/j.jum.2015.06.001

Martens, K. (2012). Justice in Transport as Justice in Accessibility: Applying Walzer's "Spheres of Justice" to The Transport Sector. Transportation, 39(6), 1035-1053. https://doi.org/10.1007/s11116-012-9388-7

Miro, F., \& Hardani, W. (2005). Perencanaan Transportasi untuk Mahasiswa, Perencana, dan Praktisi. Jakarta: Penerbit Erlangga.

Pemerintah Kota Surakarta. (2012). Peraturan Daerah Kota Surakarta Nomor 1 Tahun 2012 tentang Rencana tata Ruang Wilayah Kota Surakarta Tahun 2011-2031. Retrieved from https://pusdataru.jatengprov.go.id/dokumen/RTRW-Prov/13-Kota-Surakarta/PERDANO-1-TH-2012-KOTA-SURAKARTA.pdf

Pemerintah Kota Surakarta. Peraturan Daerah Kota Surakarta Nomor 9 Tahun 2016 Tentang Rencana Pembangunan Jangka Menengah Daerah Kota Surakarta Tahun 2016-2021. , (2016).

Samli, A. (2012). Analisis Pengembangan Kota Berdasarkan Kondisi Fisik Wilayah Kota Masohi Ibukota Kabupaten Maluku Tengah. Jurnal Plano Madani, 1(1), 74-85. Retrieved from https://media.neliti.com/media/publications/159846-ID-analisis-pengembangankota-berdasarkan-k.pdf

Sitorus, S. R. P., Leonataris, C., \& Panuju, D. R. (2012). Analisis Pola Perubahan Penggunaan Lahan Dan Perkembangan Wilayah Di Kota Bekasi, Provinsi Jawa Barat. Jurnal Ilmu Tanah Dan Lingkungan, 14(1), 21-28. https://doi.org/10.29244/jitl.14.1.21-28

Sumadi, S. H. T., Papia, F. J., \& Makainas, I. (2017). Hubungan Aksesibilitas Terhadap Tingkat Perkembangan Wilayah Kecamatan di Kota Tomohon. Jurnal Spasial, 4(1), 149-158. Retrieved from https://ejournal.unsrat.ac.id/index.php/spasial/article/view/15664

Tamim, O. Z. (2000). Perencanaan dan Pemodelan Transportasi. Bandung: Penerbit ITB. 